\title{
NACC2 Gene
}

National Cancer Institute

\section{Source}

National Cancer Institute. NACC2 Gene. NCI Thesaurus. Code C111940.

This gene plays a role in the modulation of cell proliferation. 